\title{
東京都内の主要道路における道路粉塵, 街路土袞および街路樹葉の重金属蓄積
}

\author{
白石さやか, 渡邊泉, 久野 勝治 \\ 東京農工大学農学部（テ 183-8509＼cjkstart東京都府中市幸町3-5-8）
}

[平成 14 年 7 月 30 日受理］

\section{Heavy Metal Accumulation in the Street Dust, Roadside Soil and Roadside Tree Leaves Near by Main Streets in Tokyo, Japan}

Sayaka SHIRAISHI, Izumi WATANABE and Katsuji KUNO

Department of Environmental Conservation, Tokyo University of Agriculture and Technology (3-5-8 Saiwai-cho, Fuchu, Tokyo 183-8509)

[Received July 30, 2002]

\begin{abstract}
Summary
Concentrations of $\mathrm{Mn}, \mathrm{Fe}, \mathrm{Cu}, \mathrm{Zn}, \mathrm{Cd}, \mathrm{Pt}$ and $\mathrm{Pb}$ were determined in the street dust, roadside soil and roadside tree leaves collected from main streets in Tokyo in 1997. Heavy metal concentrations in street dust increased depending on traffic density. These results suggested that automobile traffic is one of the major sources of heavy metals around streets. High concentrations of $\mathrm{Cu}, \mathrm{Zn}$ and $\mathrm{Pb}$ were found in roadside soil. Lead concentrations in our results were lower than those in some data measured about 20 years ago. This decrease trend might be attributable to regulation of tetraalkyllead use as antiknocking in gasoline.

Heavy metal concentrations in the 5 species of roadside tree leaves collected from streets of Tokyo were 1 to 4 times higher than those from reference site, and varied with each species. The highest level of heavy metals was detected in Rhododendron oomurasaki. The lowest concentration was observed in Ginkgo biroba. Concentrations of $\mathrm{Mn}, \mathrm{Fe}, \mathrm{Cd}$ and $\mathrm{Pb}$ increased from June to September generally. It was expected that these metals were binding to leaves tissue tightly. Leaf texture and plant height of roadside trees should be responsible for the different dynamics of heavy metal levels among tree species.
\end{abstract}

Key words: Heavy metals, soil pollution, roadside tree, phytoremediation

\section{1. はじめに}

2002年10月, 東京地方裁判所は東京大気污染訴訟（第 一次）で, 国や東京都, 首都高速道路公団の責任を認 め，東京都は控訴を行わないことを発表した。本訴訟
は, 自動車メーカー 7 社の責任を認めなかった判決を受 け，国拈よび原告団が控訴し東京高等裁判所に引き継が れたが，自動車走行に伴う大気污染は，いまだ都市にお ける深刻な環境問題の一つである。その原因となる物質 は，ガス状污染物質と粒子状污染物質とに大別される。 
これまで, SOxやNOxなどガス状污染物質に関する污染 防止は進展する一方で, 粒子状物質による污染は見過ご されがちであった1”。一酸化炭素や二酸化炭素に関する 改善は進んでおり，二酸化窒素についても環境基準の達 成率は増加傾向にある。しかし, 浮遊粒子状物質の環境 基準達成率は依然約 3 割と低いのが現状である。東京都 では，2003年度からディーゼル車の規制を予定してお $り^{2)}$, 粒子状物質による污染対策は今後とくに重要視さ れることが予想される。

粒子状污染物質に含まれる重金属類は, 化石燃料の燃 焼や自動車部品の磨耗などに由来し, 道路周辺環境では これらの蓄積が指摘されている ${ }^{3-5)}$ 。その代表的な例とし て, タイヤに添加されているZnやパイプ, エンジン, 車 体の部品に使用されている $\mathrm{Cu}$ および $\mathrm{Pb}$ な゙が挙げられ る。また，現在多くの乗用車で排気浄化に採用されてい る三元触媒システムでは触媒として Pt, Rh, Pdなどが 使用されており ${ }^{6)}$, 国外では道路粉塵の Pt 污染が報告さ れている゙。

豊かな街路景観の形成に不可欠な街路樹は, 人工的な 都市環境ではとくに貴重な緑化空間であり，そこで生活 する人々に潤いを与えるばかりでなく, 夏期の緑㓌の確 保, 気温上昇の緩和など, 都市環境をより快適にする役 割を果たしている ${ }^{8)}$ 。最近では, 樹木によるガス状污染 物質の浄化能に関する調査研究も進められ, いくつかの 報告は樹種間の差異を明らかにしてきた9。このことは， 樹種の選定基準により，大気浄化効果があがる可能性を 示している。粒子状污染物質に関しても, 街路植栽植物 による吸収および付着を通し, 重金属污染の拡散防止効

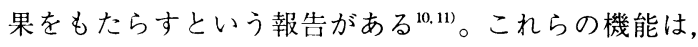
いわば広義のファイト・レメディエーションと捉えるこ とも可能であろう。さらに近年, リサイクルの一環とし て街路樹や公園樹の剪定枝を堆肥として利用する試みも あり, 今後, 既存街路樹における重金属蓄積の把握が重 要となる。

東京の都市部は, 自動車走行に伴うガス状および粒子 状物質による大気污染が, 全国でもとくに深刻な地域で あり ${ }^{1)}$, さらに人口が集中していることから, 粒子状污 染物質による健康への悪影響も懸念される。都内の大気 中浮遊粉塵の 8 割以上は, 自動車が発生源であり ${ }^{12)}$, 道
路周辺では，これらに由来する重金属污染がとくに大き くなることが予想される。本研究は, 道路粉塵, 沿道土 壤, および沿道植栽植物の葉の重金属濃度を分析するこ とで, 東京都内の主要な沿道における污染状況を明らか にし, 街路樹の葉による重金属捕捉および樹種間の差異 を検討し, 污染の拡散防止に効果的な樹種利用の可能性 を提言したい。

\section{2. 実験方法}

\section{1 試料}

東京都杉並区内の環状七号線から 3 地点, 同小金井市 内の東八道路 (新宿国立線) から 2 地点, および同調布 市内の品川通りから 2 地点を, 調査地として選定した。 各調査地付近における平日12時間の交通量は, 約 15,000 〜 48, 000台であった ${ }^{13,14)}$ 。また, 沿道環境ではない東京 都府中市の東京農工大学農学部構内を参照地とし, 選定 した全種の街路樹葉および表層土壌を採取した。

試料採取は1997年夏期に行い，7月 8 日に車道側道路 粉塵（以下, 粉塵とする) と, 沿道植栽帯の表層土壌を 採取し，同年 6 月26日，9月25日に, 街路植栽植物（以 下，街路樹とする）の葉を採取した。

粉塵は, 環状七号線の 1 地点から 2 点, 東八道路の 2 地点から 2 点ずつ計 4 点, 品川通りの 2 地点から 2 点ず つ計 4 点採取した。環状七号線における他 2 地点では, 粉塵がほとんど堆積しておらず，採取不可能であった。 沿道植栽帯の土壤は, 環状七号線から11点, 東八道路か ら14点, 品川通りから11点採取した。また街路樹種は, 国内で広く利用されている，ケヤキZelkova serrata，イ チョウ Ginkgo biloba, クスノキCinnamomum camphora, トウカエデAcer buergerianum, オオムラサキRhododendron oomurasaki 選定し, それぞれ環状七号線から 2 , $2(1) ， 3 ， 2 ， 3$ 本, 東八道路から $3 ， 5 ， 4(3), 0$, 9 本, 品川通りから $0,3,4(3), 3,6$ 本, 参照地と した東京農工大学構内から $2(1), 3(2), 2,1,2$ 本の 葉を採取した（6，9月で採取本数が異なるものは （）内が9月の採取本数)。各地点において葉を採取し た街路樹種を, Table 1に示す。

粉塵は, 縁石沿いの堆積物を絵筆とビニール袋によ り, 約 $10 \mathrm{~m}$ の範囲から $20 \mathrm{~g}$ 程度を採取した。土塞は, 各

Table 1 Five species of roadside trees and sampling locations analized heavy metal concentrations

\begin{tabular}{lcccc}
\hline & \multicolumn{4}{c}{ Location } \\
\cline { 2 - 5 } Tree species & Kanjyounanagousen & Touhachidouro & Shinagawadoori & Field of TUAT* \\
\hline Zelkova serrata & 0 & 0 & 0 & 0 \\
Ginkgo biloba & 0 & 0 & 0 & 0 \\
Cinnamomum camphora & 0 & 0 & 0 & 0 \\
Acer buergerianum & 0 & & 0 & 0 \\
Rhododendron oomurasaki & 0 & 0 & 0 \\
\hline
\end{tabular}

*Tokyo University of Agriculture and Technology locating Fuchu, Tokyo (Reference site) 
調査地および参照地とした東京農工大学構内ともに調査 樹木の根元付近より, 深さ約 $3 \mathrm{~cm}$ までを採取した。こ のとき, 地表面の落枝落葉等は取り除いた。街路樹葉の 採取高さは原則として, 路面より高木で約 $2.5 \mathrm{~m}$, 低木 で約 $0.9 \mathrm{~m}$ とし, それぞれ車道側の枝より当年葉を採取 した。

\section{2 分析方法}

粉塵及び土潩試料は, 温風乾燥機にて $105^{\circ} \mathrm{C} て ゙ 1$ 週間 以上乾燥させ, 粉塵は $0.5 \mathrm{~mm}$ 以下, 土壌は $2.0 \mathrm{~mm}$ 以下 に笠別した。調整した試料は既報 ${ }^{15.16}$ に従い，粉塵約 $2.0 \mathrm{~g}$ (不足するものは全量), 土壤は約 $5.0 \mathrm{~g}$ を $300 \mathrm{~m} \ell$ 容 トールビーカーに秤取し, 硝酸 $30 \mathrm{~m} \ell$ および過塩素酸 $10 \mathrm{~m} \ell$ を加え, 時計血で蓋をして $270^{\circ} \mathrm{C}$ の砂浴上で加熱分 解を行った。ビーカー内の褐色蒸気が消えた後に時計血 を外し, 蒸発乾固後, 温浴中で加温した $1 \mathrm{~N}$ 塩酸 $20 \mathrm{~m} \ell$ を加え, 抽出, 濾過した。滤液は $1 \mathrm{~N}$ 塩酸で $50 \mathrm{~m} \ell$ に定容 し, 試料溶液とした。また, 箳別後の土壤は, 既報 従い土壤 $\mathrm{pH}\left(\mathrm{H}_{2} \mathrm{O}\right)$ を測定した。

街路樹の葉は, 葉表面に付着した粉塺の影響を評価す るため, 採取試料の約半量を洗浄し, 洗浄試料, 残りは 未洗浄試料として供試した。洗浄液は硝酸, 硫酸, 塩酸 の混合液に純水 (YAMATO MILLIPORE WQ500) を加 え, 日本の雨水の平均 $\mathrm{pH}$ である $\mathrm{pH} 4.7$ に調整した。乾 重で約 $1.0 \mathrm{~g}$ 相当の生葉を, $250 \mathrm{~m} \ell$ の洗浄液を用い, 振と う数 $140 \mathrm{rpm}$, 振とう幅 $30 \mathrm{~mm}$ で30分間洗浄した。洗浄葉 および末洗浄葉はともに, 温風乾燥機にて $60^{\circ} \mathrm{C} て ゙ 72$ 時間 乾燥させ, 乾重量約 $1.0 \mathrm{~g}$ を $300 \mathrm{~m} \ell$ 容トールビーカーに 秤取し, 粉塵および土壤試料と同様に, 硝酸, 過塩素酸 を用いて湿式灰化した。但し, 硝酸は $30 \mathrm{~m} \ell$, 過塩素酸 は $6 \mathrm{~m} \ell$ を添加した。分解終了後, 加熱した $1 \mathrm{~N}$ 塩酸 $10 \mathrm{~m} \ell$ を加えて抽出, 濾過し, 試料溶液とした。試料溶 液は原子吸光光度計 (日立 Z-6100型) で, $\mathrm{Mn}, \mathrm{Fe}, \mathrm{Cu}$, $\mathrm{Zn}, \mathrm{Cd}, \mathrm{Pt}, \mathrm{Pb}$ 濃度を測定した。フレームは全て空気一 アセチレンを用い, 分析の精密さは繰り返し測定で確認
し、いずれの元素も RSD 3 \%以内であった。

\section{3. 結果および考察}

\section{1 道路粉塵}

分析した道路粉鹿の重金属濃度を, Table 2に示す。粉 塵の重金属濃度は，交通量が最大であった環状七号線に おいて最も高く, 交通量の増加に伴い上昇した。この上 昇は交通量によって変化する傾向を示し, 品川通り（交 通量 14,613 台 $/ 12$ 時間) - 東八道路（同，25,054）間上 りも東八道路一環状七号線（同，47,795）間の方が急激 であった。各元素濃度について, 軽度の污染地と考えら れる国内の山岳部における道路粉塵濃度 ${ }^{16)}$, および地款 における存在度 ${ }^{18,19)}$ と比較し，2つの元素グループに大 別した。即ち $\mathrm{Cu}, \mathrm{Zn}, \mathrm{Cd}, \mathrm{Pb}$ は, 粉塵で高濃度で検出 され， Mn, Fe は低濃度グループであった。また，東京 都における過去 20 年間での変化を検討するため, 本調査 結果に扔ける全地点の平均濃度と，1977年に調査された 東京23区内の道路粉塵濃度20) とを比較した。その結果, とくに $\mathrm{Pb}$ に著しい濃度の低下が認められた（Fig. 1)。 $\mathrm{Pb}$ 濃度の低下は, 1975年に鉛添加ガソリンの販売が禁 止されたことの影響を受けたものと推察された。さら に，Zn拈よびその不純物として随伴していることが知 られる $\mathrm{Cd}$ の濃度も減少傾向が認められた。都区部にお ける交通量は近年減少傾向にあり ${ }^{21)}$, これらの元素濃度 の低下には，交通量の変動も関与している可能性が考え られたが, 今後の継続的かつ詳細な調査が必要であろ う。とくに，2003年から実施される2 都内における ディーゼル車の規制は, この移動放出源が環境へ負荷す る微量元素レベルが大きいだけに，今後の沿道環境にお ける元素レベルを劇的に変化させることが予測される。

\section{2 街路土壤}

街路土壤の重金属濃度を Table 3に示す。すべての土 壤試料から, Pt は検出されなかった。街路土壤の $\mathrm{Cu}$, $\mathrm{Zn}, \mathrm{Cd}, \mathrm{Pb}$ 濃度は, 参照地土壤の約 2 倍であった。参照

Table 2 Heavy metal concentrations (Mean $\pm \mathrm{SD}$ on dry weight basis) in the street dust collected from 3 main streets of Tokyo on July in 1997

\begin{tabular}{|c|c|c|c|c|c|c|c|c|}
\hline Location & $\begin{array}{l}\text { Traffic density } \\
12 \mathrm{~h}^{-1} \text { daytime }\end{array}$ & $\begin{array}{c}\mathrm{Mn} \\
\mu \mathrm{g} \mathrm{g}^{-1} \\
\end{array}$ & $\begin{array}{l}\mathrm{Fe} \\
\% \\
\end{array}$ & $\begin{array}{c}\mathrm{Cu} \\
\mu \mathrm{g} \mathrm{g}^{-1} \\
\end{array}$ & $\begin{array}{c}\mathrm{Zn} \\
\mu \mathrm{gg}^{-1} \\
\end{array}$ & $\begin{array}{c}\mathrm{Cd} \\
\mu \mathrm{g} \mathrm{g}^{-1}\end{array}$ & $\begin{array}{c}\mathrm{Pt} \\
\mu \mathrm{g} \mathrm{g}^{-1} \\
\end{array}$ & $\begin{array}{c}\mathrm{Pb} \\
\mu \mathrm{g} \mathrm{g}^{-1} \\
\end{array}$ \\
\hline Kanjyounanagousen & 47795 & 510 & 2.9 & $\begin{array}{l}300 \\
\text { (2) }\end{array}$ & 890 & 0.49 & 3.1 & 180 \\
\hline Touhachidouro & 25054 & $\begin{array}{c}350 \pm 28 \\
(4)\end{array}$ & $\begin{array}{c}1.7 \pm 0.1 \\
(4)\end{array}$ & $\begin{array}{c}160 \pm 59 \\
(4)\end{array}$ & $430 \pm 140$ & $\begin{array}{c}0.34 \pm 0.12 \\
(4)\end{array}$ & $\begin{array}{c}0.5 \pm 0.3 \\
(4)\end{array}$ & $\begin{array}{c}58 \pm 7 \\
(4)\end{array}$ \\
\hline Shinagawadoori & 14613 & $\begin{array}{c}340 \pm 16 \\
(4)\end{array}$ & $\begin{array}{c}1.8 \pm 0.1 \\
\text { (4) }\end{array}$ & $\begin{array}{c}180 \pm 84 \\
\text { (4) }\end{array}$ & $\begin{array}{c}310 \pm 27 \\
(4)\end{array}$ & $\begin{array}{c}0.23 \pm 0.04 \\
\text { (4) }\end{array}$ & $\begin{array}{c}0.1 \pm 0.1 \\
\text { (4) }\end{array}$ & $\begin{array}{c}53 \pm 19 \\
\text { (4) }\end{array}$ \\
\hline
\end{tabular}

Number of samples is in parentheses. 


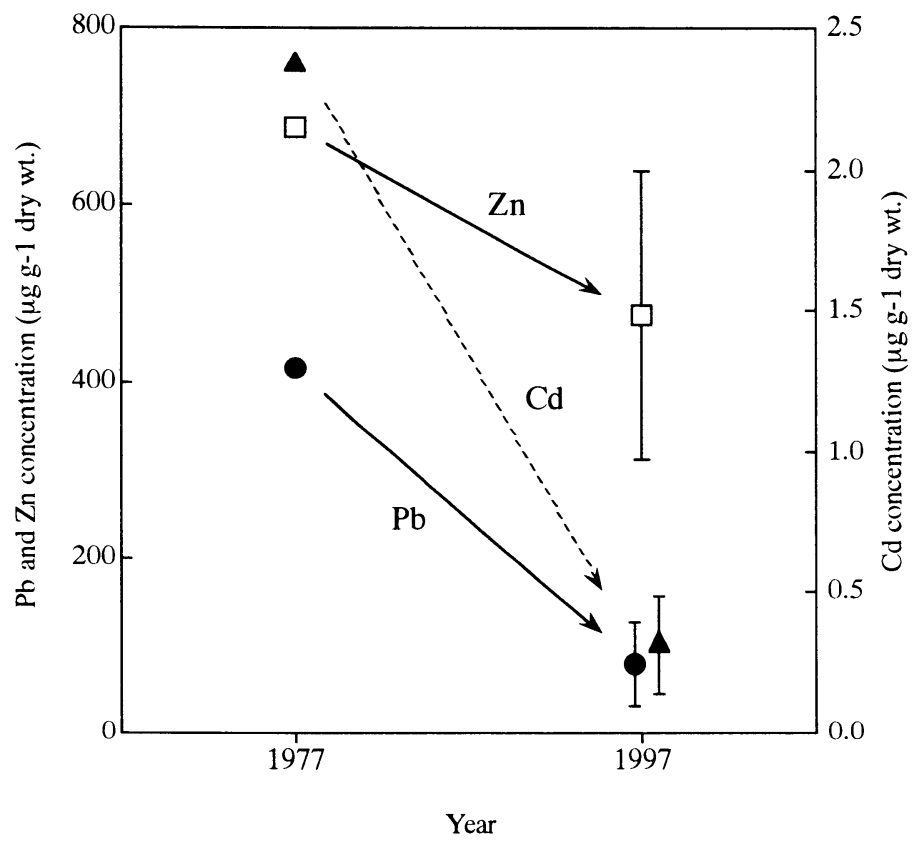

Fig. $1 \mathrm{Zn}, \mathrm{Pb}$ and $\mathrm{Cd}$ concentrations in the street dust collected from Tokyo in 1977 and 1997. The former data was quoted from Asami \& Teshima (1978)

Table 3 Heavy metal concentrations (Mean $\pm \mathrm{SD}$ on dry weight basis) and $\mathrm{pH}$ in the roadside soil collected from each location around Tokyo on July in 1997

\begin{tabular}{|c|c|c|c|c|c|c|c|c|}
\hline Location & $\begin{array}{l}\text { Traffic density } \\
12 \mathrm{~h}^{-1} \text { daytime }\end{array}$ & $\begin{array}{c}\mathrm{Mn} \\
\mu \mathrm{g} \mathrm{g}^{-1}\end{array}$ & $\begin{array}{l}\mathrm{Fe} \\
\% \\
\end{array}$ & $\begin{array}{c}\mathrm{Cu} \\
\mu \mathrm{g} \mathrm{g}^{-1}\end{array}$ & $\begin{array}{c}\mathrm{Zn} \\
\mu \mathrm{g} \mathrm{g}^{-1}\end{array}$ & $\begin{array}{c}\mathrm{Cd} \\
\mu \mathrm{g} \mathrm{g}^{-1}\end{array}$ & $\begin{array}{c}\mathrm{Pb} \\
\mu \mathrm{g} \mathrm{g}^{-1} \\
\end{array}$ & $\mathrm{pH}\left(\mathrm{H}_{2} \mathrm{O}\right)$ \\
\hline Kanjyounanagousen & 47795 & $\begin{array}{c}680 \pm 110 \\
\text { (11) }\end{array}$ & $\begin{array}{c}3.7 \pm 0.8 \\
(11)\end{array}$ & $\begin{array}{c}120 \pm 65 \\
(11)\end{array}$ & $\begin{array}{c}430 \pm 170 \\
(11)\end{array}$ & $\begin{array}{c}0.50 \pm 0.21 \\
(11)\end{array}$ & $\begin{array}{c}73 \pm 34 \\
(11)\end{array}$ & $\begin{array}{c}6.0 \pm 0.4 \\
(11)\end{array}$ \\
\hline Touhachidouro & 25054 & $\begin{array}{c}660 \pm 240 \\
(14)\end{array}$ & $\begin{array}{c}4.1 \pm 0.7 \\
(14)\end{array}$ & $\begin{array}{c}120 \pm 20 \\
(14)\end{array}$ & $\begin{array}{c}310 \pm 77 \\
(14)\end{array}$ & $\begin{array}{c}0.48 \pm 0.10 \\
(14)\end{array}$ & $\begin{array}{c}62 \pm 38 \\
(14)\end{array}$ & $\begin{array}{c}5.4 \pm 0.4 \\
\text { (14) }\end{array}$ \\
\hline Shinagawadoori & 14613 & $\begin{array}{c}760 \pm 68 \\
\text { (11) }\end{array}$ & $\begin{array}{c}4.0 \pm 0.4 \\
(11)\end{array}$ & $\begin{array}{c}110 \pm 27 \\
(11)\end{array}$ & $\begin{array}{c}370 \pm 85 \\
(11)\end{array}$ & $\begin{array}{c}0.52 \pm 0.12 \\
(11)\end{array}$ & $\begin{array}{c}70 \pm 25 \\
(11)\end{array}$ & $\begin{array}{c}6.0 \pm 0.3 \\
(11)\end{array}$ \\
\hline Field of TUAT* & 0 & $\begin{array}{c}490 \pm 140 \\
(12)\end{array}$ & $\begin{array}{c}2.9 \pm 1.0 \\
(12)\end{array}$ & $\begin{array}{c}53 \pm 22 \\
(12)\end{array}$ & $\begin{array}{c}210 \pm 60 \\
(12)\end{array}$ & $\begin{array}{c}0.38 \pm 0.09 \\
(12)\end{array}$ & $\begin{array}{c}36 \pm 14 \\
(12)\end{array}$ & $\begin{array}{c}6.2 \pm 0.4 \\
(12)\end{array}$ \\
\hline
\end{tabular}

Number of samples is in parentheses.

*Tokyo University of Agriculture and Technology locating Fuchu, Tokyo (Reference site)

地における土壤の重金属濃度は全体的に, 山岳部の森林 土壤 ${ }^{(6)}$ や地款の濃度 ${ }^{(8)}$ と同程度であったが, $\mathrm{Cu}$ および $\mathrm{Zn}$ については，2 倍以上の值が検出された。これらの結果 は, $\mathrm{Cu}, \mathrm{Zn}, \mathrm{Cd}, \mathrm{Pb}$ による沿道周辺土壤の污染を示唆 していると考えられ, 付近の生産緑地などへの生態影響 も懸念された。さらにCuおよび Znについては, 街路環 境に留まらず，より遠方の土壤までも污染が拡散する可 能性が示唆され, とくに Znによる広域污染は著しい可 能性が推察された。本調査からは, 街路土壤および参照 地土壤ともに, Mn, Fe, Ptによる污染レベルは低いこ
とがうかがえた。

土壤の重金属濃度は, 全元素ともに参照地として設定 した非街路の土䁃において最低値を示した。また, 道路 粉塵と同様に交通量の増加に伴う上昇傾向がみられた。 しかし，そのパターンは粉塵に比べ顕著ではなく，交通 量が最も少ない品川通りでやや高濃度となった。この一 因として, 街路の植栽状況が異なることが考えられた。 つまり, 東八道路の植栽帯は低木, 中高木, 高木から成 り, 本調査を行った 3 地点内で最も密な列植で形成され ており, 一方, 品川通りの植栽は最も疎であった。この 


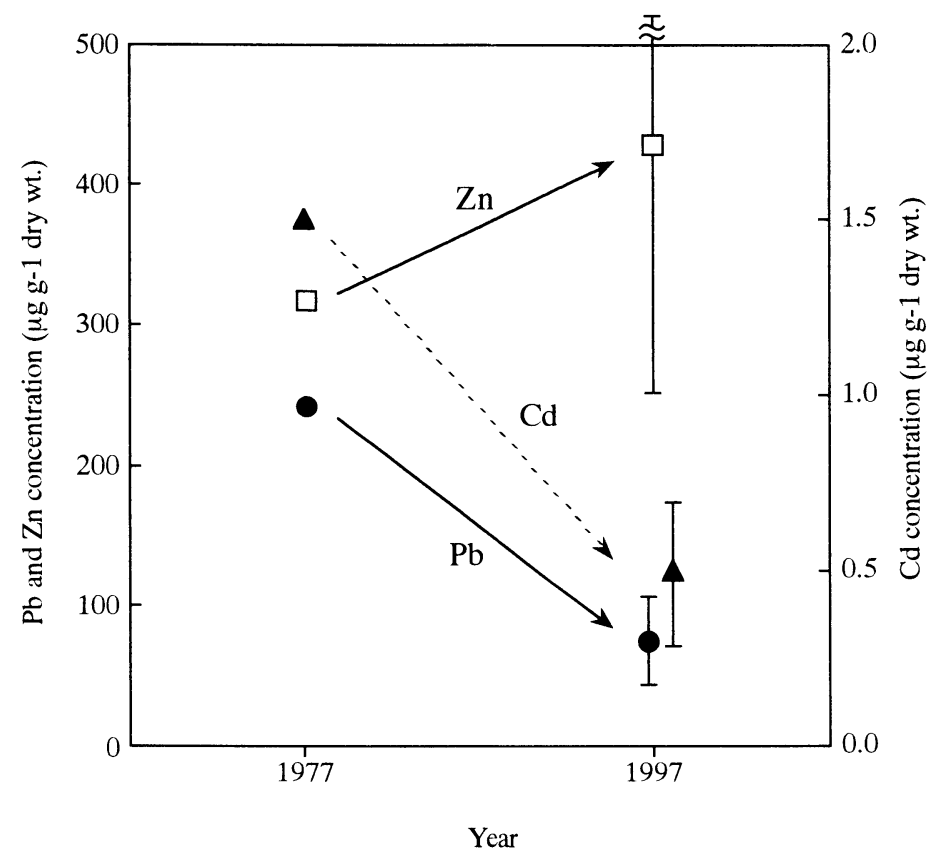

Fig. $2 \mathrm{Zn}, \mathrm{Pb}$ and $\mathrm{Cd}$ concentrations in the roadside soils collected from Chiba in 1972 and Tokyo in 1997. The former data was quoted from Shimada et al. (1973)

ため品川通りに扔いては, 車道に由来した比較的高いレ ベルの重金属類を含む粉塵が, 街路樹により補足されず 直接, 土袞表面に蓄積し，このような地域差を生じた可 能性が考えられた。

また，環状七号線に扔ける土壤について，同程度の交 通量であった千葉県の国道（交通量約40,000台／日）沿 いで1972年に測定された土壤の重金属分析結果 ${ }^{22}$ と比較 すると, $\mathrm{Zn}$ 濃度は同程度であったのに対して, $\mathrm{Pb}$ およ びCd濃度が低かった（Fig. 2)。この傾向は3.1で示し た，粉鹿の結果と同様の傾向であった。しかし，これら の值は山岳部の森林土壤(6) と比較すると依然高濃度とい え, 本研究が実施された1997年に掞いても污染が存続し ていることを示している。

\section{3 道路粉塵と街路土壤の比較}

道路粉塵に打ける重金属類の起源として, 以下の 2 通 りの経路が考えられた。1つは周辺の土㙵粒子が風や降 雨の作用により巻き上げられ, 道路脇に蓄積することに 由来するもので, いわばバックグラウンドと類似した值 として評価できる。もう一方は, 自動車の排気ガスや車 体部品の摩耗といった自動車を起源として, 環境中に放 出される経路である。粉塵の重金属濃度に関して, 品川 通りの $\mathrm{Mn}, \mathrm{Fe}, \mathrm{Zn}, \mathrm{Cd}, \mathrm{Pb}$, 東八道路の $\mathrm{Mn}, \mathrm{Fe}, \mathrm{Cd}$, $\mathrm{Pb}$ 㧍よび環状七号線の $\mathrm{Mn}, \mathrm{Fe}, \mathrm{Cd}$ は, 同調査地点にお ける土壌の濃度より低かった。このことから, 粉塵に含
まれるこれら重金属類は, 主に街路土堙に由来すると推 察された。一方, 品川通りの $\mathrm{Cu}$ と $\mathrm{Pt}$, 東八道路の $\mathrm{Cu}$, $\mathrm{Zn}, \mathrm{Pt}$ 㧍よび環状七号線の $\mathrm{Cu}, \mathrm{Zn}, \mathrm{Pt}, \mathrm{Pb}$ は, 粉塵の 濃度の方が土壤よりも高く, 後者, つまり自動車を起源 として蓄積したものと推察された。土壤よりも粉塵でよ り高濃度が検出された元素数は, 交通量が最大であった 環状七号線で 4 種と最も多く, 道路において交通量が増 加するほど, 前者よりも後者の経路の寄与が大きくなる ことが示された。

また本研究において, 土壤から Pt は検出されなかっ たが, 粉塵では検出され, さらに交通量に依存した濃度 上昇も認められた。このことから, Ptによる土壤污染の 進行も懸念され, 今後はこの元素に注目したモニタリン グも必要となろう。

\section{4 街路樹葉}

6 月および 9 月に採取した街路樹葉の重金属濃度を Table 4, 5に示す。街路樹の葉から Pt は検出されず, ま た 6 月の洗浄葉からは $\mathrm{Cd}$ も検出されなかった。各元素 濃度は, 洗浄葉, 未洗浄葉ともに参照地に打いて最も低 く, 他の 3 調查地点間では同レベルを示す傾向がみられ た。

街路樹葉の重金属濃度は，樹種による違いが大きく， 採取地を問わず，またほとんどの元素において, 洗浄葉 および未洗浄葉ともにオオムラサキが最高值を示し，一 
Table 4 Heavy metal concentrations (Mean $\pm \mathrm{SD}$ on $\mu \mathrm{g} \mathrm{g}^{-1}$ dry weight basis) in the leaves of roadside trees collected from each location around Tokyo on June in 1997

\begin{tabular}{|c|c|c|c|c|c|c|c|c|}
\hline \multirow{2}{*}{ Tree species } & \multirow{2}{*}{ Reference site } & \multicolumn{3}{|c|}{ WASHED } & \multirow[b]{2}{*}{ Reference site } & \multirow{2}{*}{$\begin{array}{l}\text { UNY } \\
\text { Shinagawadoori }\end{array}$} & \multirow{2}{*}{$\begin{array}{l}\text { HED } \\
\text { Touhachidouro }\end{array}$} & \multirow[b]{2}{*}{ Kanjyounanagousen } \\
\hline & & Shinagawadoori & Touhachidouro & Kanjyounanagousen & & & & \\
\hline & \multicolumn{4}{|c|}{$\mathrm{Mn}$} & \multicolumn{4}{|c|}{$\mathrm{Mn}$} \\
\hline Zelkova serrata & $\begin{array}{c}37 \pm 3 \\
(7)\end{array}$ & NA & $\begin{array}{c}62 \pm 8 \\
(10)\end{array}$ & $\begin{array}{r}41 \pm 5 \\
(4)\end{array}$ & $\begin{array}{c}43 \pm 0.3 \\
(7)\end{array}$ & $\mathrm{NA}$ & $82 \pm 26$ & $\begin{array}{c}49 \pm 4 \\
(4)\end{array}$ \\
\hline Ginkgo biloba & $\begin{array}{c}14 \pm 3 \\
(8)\end{array}$ & $\begin{array}{c}18 \pm 2 \\
(9)\end{array}$ & $\begin{array}{c}19 \pm 7 \\
(13)\end{array}$ & $\begin{array}{c}15 \pm 3 \\
(4)\end{array}$ & $\begin{array}{c}17 \pm 3 \\
(8)\end{array}$ & $\begin{array}{c}21 \pm 2 \\
(9)\end{array}$ & $\begin{array}{r}24 \pm 8 \\
(18)\end{array}$ & $\begin{array}{c}19 \pm 0.4 \\
(6)\end{array}$ \\
\hline Cinnamomum camphora & $\begin{array}{c}32 \pm 4 \\
(5)\end{array}$ & $\begin{array}{c}33 \pm 8 \\
(11)\end{array}$ & $\begin{array}{c}52 \pm 11 \\
(13)\end{array}$ & $\begin{array}{c}78 \pm 13 \\
(7)\end{array}$ & $\begin{array}{c}44 \pm 2 \\
(3)\end{array}$ & $\begin{array}{c}43 \pm 11 \\
(15)\end{array}$ & $\begin{array}{c}60 \pm 12 \\
(12)\end{array}$ & $\begin{array}{c}96 \pm 18 \\
(8)\end{array}$ \\
\hline Acer buergerianum & $\begin{array}{c}27 \pm 4 \\
(6)\end{array}$ & $\begin{array}{c}34 \pm 8 \\
(9)\end{array}$ & NA & $\begin{array}{c}40 \pm 10 \\
(5)\end{array}$ & $35 \pm 2$ & $\begin{array}{c}42 \pm 11 \\
(11)\end{array}$ & NA & $\begin{array}{c}52 \pm 14 \\
(6)\end{array}$ \\
\hline \multirow[t]{2}{*}{ Rhododendron oomurasaki } & $\begin{array}{r}27 \pm 4 \\
(14)\end{array}$ & $\begin{array}{c}38 \pm 9 \\
(12)\end{array}$ & $\begin{array}{c}44 \pm 13 \\
(18)\end{array}$ & $\begin{array}{c}41 \pm 7 \\
(6)\end{array}$ & $\begin{array}{c}35 \pm 5 \\
(8)\end{array}$ & $\begin{array}{c}46 \pm 11 \\
(16)\end{array}$ & $\begin{array}{c}57 \pm 20 \\
(20)\end{array}$ & $\begin{array}{c}51 \pm 14 \\
(7)\end{array}$ \\
\hline & \multicolumn{4}{|c|}{$\mathrm{Fe}$} & \multicolumn{4}{|c|}{$\mathrm{Fe}$} \\
\hline Zelkova serrata & $\begin{array}{c}224 \pm 15 \\
(7)\end{array}$ & NA & $\begin{array}{c}230 \pm 44 \\
(10)\end{array}$ & $\begin{array}{c}210 \pm 45 \\
(4)\end{array}$ & $\begin{array}{c}300 \pm 71 \\
(7)\end{array}$ & NA & $\begin{array}{c}320 \pm 75 \\
(9)\end{array}$ & $\begin{array}{c}270 \pm 29 \\
(4)\end{array}$ \\
\hline Ginkgo biloba & $\begin{array}{c}83 \pm 24 \\
(8)\end{array}$ & $\begin{array}{c}180 \pm 45 \\
(9)\end{array}$ & $\begin{array}{c}160 \pm 37 \\
(13)\end{array}$ & $\begin{array}{c}160 \pm 28 \\
(4)\end{array}$ & $\begin{array}{c}130 \pm 24 \\
(8)\end{array}$ & $\begin{array}{c}250 \pm 57 \\
(9)\end{array}$ & $\begin{array}{c}220 \pm 46 \\
(18)\end{array}$ & $\begin{array}{c}180 \pm 42 \\
(6)\end{array}$ \\
\hline Cinnamomum camphora & $\begin{array}{c}103 \pm 6 \\
(5)\end{array}$ & $\begin{array}{c}210 \pm 63 \\
(11)\end{array}$ & $\begin{array}{c}140 \pm 21 \\
(13)\end{array}$ & $\begin{array}{c}220 \pm 30 \\
(7)\end{array}$ & $\begin{array}{c}160 \pm 7 \\
(3)\end{array}$ & $\begin{array}{c}300 \pm 100 \\
(15)\end{array}$ & $\begin{array}{c}200 \pm 15 \\
(12)\end{array}$ & $\begin{array}{c}260 \pm 35 \\
(8)\end{array}$ \\
\hline Acer buergerianum & $\begin{array}{c}117 \pm 20 \\
(6)\end{array}$ & $\begin{array}{c}180 \pm 19 \\
(9)\end{array}$ & NA & $\begin{array}{c}250 \pm 23 \\
(5)\end{array}$ & $\begin{array}{c}180 \pm 52 \\
(5)\end{array}$ & $\begin{array}{l}290 \pm 66 \\
(11)\end{array}$ & NA & $\begin{array}{c}280 \pm 80 \\
(6)\end{array}$ \\
\hline \multirow[t]{2}{*}{ Rhododendron oomurasaki } & $\begin{array}{c}287 \pm 51 \\
(14)\end{array}$ & $\begin{array}{c}610 \pm 100 \\
(12)\end{array}$ & $\begin{array}{c}510 \pm 106 \\
(18)\end{array}$ & $\begin{array}{c}570 \pm 110 \\
(6)\end{array}$ & $\begin{array}{c}460 \pm 24 \\
(8)\end{array}$ & $\begin{array}{c}810 \pm 100 \\
(16)\end{array}$ & $\begin{array}{c}780 \pm 180 \\
(20)\end{array}$ & $\begin{array}{c}750 \pm 140 \\
(7)\end{array}$ \\
\hline & \multicolumn{4}{|c|}{$\mathrm{Cu}$} & \multicolumn{4}{|c|}{$\mathrm{Cu}$} \\
\hline Zelkova serrata & $\begin{array}{c}6.2 \pm 0.6 \\
(7)\end{array}$ & NA & $\begin{array}{c}6.4 \pm 1.9 \\
(10)\end{array}$ & $\begin{array}{c}8.1 \pm 0.5 \\
(4)\end{array}$ & $\begin{array}{c}6.6 \pm 0.5 \\
(7)\end{array}$ & NA & $\begin{array}{c}7.2 \pm 2.2 \\
(9)\end{array}$ & $\begin{array}{c}10 \pm 1 \\
(4)\end{array}$ \\
\hline Ginkgo biloba & $\begin{array}{c}2.6 \pm 0.4 \\
(8)\end{array}$ & $\begin{array}{c}4.6 \pm 0.6 \\
(9)\end{array}$ & $\begin{array}{c}4.2 \pm 0.7 \\
(13)\end{array}$ & $\begin{array}{c}2.9 \pm 0.3 \\
(4)\end{array}$ & $\begin{array}{c}3.0 \pm 0.5 \\
(8)\end{array}$ & $\begin{array}{c}5.4 \pm 0.3 \\
(9)\end{array}$ & $\begin{array}{c}4.6 \pm 0.5 \\
(18)\end{array}$ & $\begin{array}{c}3 \pm 1 \\
(6)\end{array}$ \\
\hline Cinnamomum camphora & $\begin{array}{c}6.1 \pm 0.1 \\
(5)\end{array}$ & $\begin{array}{c}9.2 \pm 2.1 \\
(11)\end{array}$ & $\begin{array}{c}7.1 \pm 1.4 \\
(13)\end{array}$ & $\begin{array}{c}10 \pm 1 \\
(7)\end{array}$ & $\begin{array}{c}6.3 \pm 0.2 \\
(3)\end{array}$ & $\begin{array}{r}10 \pm 3 \\
(15)\end{array}$ & $\begin{array}{c}7.8 \pm 1.6 \\
(12)\end{array}$ & $\begin{array}{c}12 \pm 2 \\
(8)\end{array}$ \\
\hline Acer buergerianum & $\begin{array}{c}6.5 \pm 1.0 \\
(6)\end{array}$ & $\begin{array}{c}8.9 \pm 1.8 \\
(9)\end{array}$ & NA & $\begin{array}{c}14 \pm 2 \\
(5)\end{array}$ & $\begin{array}{c}7.7 \pm 0.9 \\
(5)\end{array}$ & $\begin{array}{r}11 \pm 2 \\
(11)\end{array}$ & NA & $\begin{array}{c}15 \pm 1 \\
(6)\end{array}$ \\
\hline \multirow[t]{2}{*}{ Rhododendron oomurasaki } & $\begin{array}{c}9.7 \pm 0.7 \\
(14)\end{array}$ & $\begin{array}{c}12 \pm 3 \\
(12)\end{array}$ & $\begin{array}{r}13 \pm 1 \\
(18)\end{array}$ & $\begin{array}{c}19 \pm 3 \\
(6)\end{array}$ & $\begin{array}{c}10 \pm 0.3 \\
(8)\end{array}$ & $\begin{array}{r}14 \pm 2 \\
(16)\end{array}$ & $\begin{array}{r}15 \pm 2 \\
(20)\end{array}$ & $20 \pm 3$ \\
\hline & \multicolumn{4}{|c|}{$\mathrm{Zn}$} & \multicolumn{4}{|c|}{$\mathrm{Zn}$} \\
\hline Zelkova serrata & $\begin{array}{c}11 \pm 1 \\
(7)\end{array}$ & NA & $\begin{array}{c}27 \pm 10 \\
(10)\end{array}$ & $\begin{array}{c}24 \pm 5 \\
(4)\end{array}$ & $\begin{array}{c}11 \pm 1 \\
(7)\end{array}$ & NA & $\begin{array}{c}33 \pm 5 \\
(9)\end{array}$ & $\begin{array}{c}29 \pm 2 \\
(4)\end{array}$ \\
\hline Ginkgo biloba & $\begin{array}{c}7 \pm 2 \\
(8)\end{array}$ & $\begin{array}{c}14 \pm 2 \\
(9)\end{array}$ & $\begin{array}{r}11 \pm 5 \\
(13)\end{array}$ & $\begin{array}{c}7 \pm 2 \\
(4)\end{array}$ & $\begin{array}{c}7 \pm 1 \\
(8)\end{array}$ & $\begin{array}{c}20 \pm 2 \\
(9)\end{array}$ & $\begin{array}{c}15 \pm 4 \\
(18)\end{array}$ & $\begin{array}{c}11 \pm 1 \\
(6)\end{array}$ \\
\hline Cinnamomum camphora & $\begin{array}{c}18 \pm 2 \\
(5)\end{array}$ & $\begin{array}{c}36 \pm 11 \\
(11)\end{array}$ & $\begin{array}{c}24 \pm 7 \\
(13)\end{array}$ & $25 \pm 2$ & $\begin{array}{c}18 \pm 0.4 \\
(3)\end{array}$ & $\begin{array}{c}46 \pm 12 \\
(15)\end{array}$ & $\begin{array}{c}26 \pm 5 \\
(12)\end{array}$ & $\begin{array}{c}31 \pm 5 \\
(8)\end{array}$ \\
\hline Acer buergerianum & $\begin{array}{c}27 \pm 4 \\
(6)\end{array}$ & $\begin{array}{c}41 \pm 9 \\
(9)\end{array}$ & NA & $\begin{array}{c}52 \pm 10 \\
(5)\end{array}$ & $\begin{array}{c}28 \pm 1 \\
(5)\end{array}$ & $\begin{array}{c}49 \pm 8 \\
(11)\end{array}$ & NA & $\begin{array}{c}55 \pm 5 \\
(6)\end{array}$ \\
\hline \multirow[t]{2}{*}{ Rhododendron oomurasaki } & $\begin{array}{r}36 \pm 2 \\
(14)\end{array}$ & $\begin{array}{c}99 \pm 17 \\
(12)\end{array}$ & $\begin{array}{c}72 \pm 16 \\
(18)\end{array}$ & $\begin{array}{c}85 \pm 12 \\
(6)\end{array}$ & $\begin{array}{c}37 \pm 2 \\
(8)\end{array}$ & $\begin{array}{c}120 \pm 24 \\
(16)\end{array}$ & $\begin{array}{c}85 \pm 17 \\
(20)\end{array}$ & $\begin{array}{c}90 \pm 12 \\
(7)\end{array}$ \\
\hline & \multicolumn{4}{|c|}{$\mathrm{Cd}$} & \multicolumn{4}{|c|}{$\mathrm{Cd}$} \\
\hline Zelkova serrata & ND & NA & ND & ND & $0.01 \pm 0.003$ & NA & $\begin{array}{c}0.02 \pm 0.01 \\
(9)\end{array}$ & $\begin{array}{c}0.02 \pm 0.01 \\
(4)\end{array}$ \\
\hline Ginkgo biloba & ND & ND & ND & ND & $\begin{array}{c}0.00 \pm 0.004 \\
(5)\end{array}$ & $\begin{array}{c}0.01 \pm 0.01 \\
(8)\end{array}$ & $\begin{array}{c}0.01 \pm 0.004 \\
(14)\end{array}$ & $\begin{array}{c}0.01 \pm 0.01 \\
(6)\end{array}$ \\
\hline Cinnamomum camphora & ND & ND & ND & ND & $\begin{array}{c}0.02 \pm 0.004 \\
(3)\end{array}$ & $\begin{array}{c}0.06 \pm 0.02 \\
(15)\end{array}$ & $\begin{array}{c}0.05 \pm 0.02 \\
(12)\end{array}$ & $\begin{array}{c}0.08 \pm 0.05 \\
(8)\end{array}$ \\
\hline Acer buergerianum & ND & ND & NA & ND & $\begin{array}{c}0.04 \pm 0.03 \\
(5)\end{array}$ & $\begin{array}{c}0.05 \pm 0.01 \\
(11)\end{array}$ & NA & $\begin{array}{c}0.05 \pm 0.01 \\
(6)\end{array}$ \\
\hline \multirow[t]{2}{*}{ Rhododendron oomurasaki } & ND & ND & ND & ND & $\begin{array}{c}0.14 \pm 0.01 \\
(8)\end{array}$ & $\begin{array}{c}0.17 \pm 0.05 \\
(16)\end{array}$ & $\begin{array}{c}0.31 \pm 0.09 \\
(20)\end{array}$ & $\begin{array}{c}0.25 \pm 0.09 \\
(7)\end{array}$ \\
\hline & \multicolumn{4}{|c|}{$\mathrm{Pb}$} & \multicolumn{4}{|c|}{$\mathrm{Pb}$} \\
\hline Zelkova serrata & $\begin{array}{c}1.3 \pm 0.2 \\
(7)\end{array}$ & NA & $\begin{array}{c}1.4 \pm 0.4 \\
(9)\end{array}$ & $\begin{array}{c}1.7 \pm 0.5 \\
(4)\end{array}$ & $\begin{array}{c}1.8 \pm 0.3 \\
(7)\end{array}$ & NA & $\begin{array}{c}2.2 \pm 0.5 \\
(9)\end{array}$ & $\begin{array}{c}2.6 \pm 0.5 \\
(4)\end{array}$ \\
\hline Ginkgo biloba & $\begin{array}{c}0.9 \pm 0.4 \\
(8)\end{array}$ & $\begin{array}{c}1.1 \pm 0.5 \\
(7)\end{array}$ & $\begin{array}{c}1.0 \pm 0.5 \\
(12)\end{array}$ & $\begin{array}{c}1.0 \pm 0.5 \\
(4)\end{array}$ & $\begin{array}{c}1.0 \pm 0.3 \\
(8)\end{array}$ & $\begin{array}{c}1.3 \pm 0.1 \\
(9)\end{array}$ & $\begin{array}{c}1.4 \pm 0.6 \\
(18)\end{array}$ & $\begin{array}{c}1.4 \pm 1.0 \\
(6)\end{array}$ \\
\hline Cinnamomum camphora & $\begin{array}{c}0.1 \pm 0.1 \\
(4)\end{array}$ & $\begin{array}{c}2.0 \pm 0.6 \\
(8)\end{array}$ & $\begin{array}{c}1.2 \pm 0.8 \\
(12)\end{array}$ & $\begin{array}{c}0.8 \pm 0.4 \\
(5)\end{array}$ & $\begin{array}{c}1.0 \pm 0.2 \\
(3)\end{array}$ & $\begin{array}{c}2.8 \pm 1.0 \\
(12)\end{array}$ & $\begin{array}{c}2.0 \pm 0.4 \\
(12)\end{array}$ & $\begin{array}{c}2.2 \pm 0.7 \\
(8)\end{array}$ \\
\hline Acer buergerianum & $\begin{array}{c}0.8 \pm 0.2 \\
(6)\end{array}$ & $\begin{array}{c}1.3 \pm 0.3 \\
(7)\end{array}$ & NA & $\begin{array}{c}1.0 \pm 0.4 \\
(4)\end{array}$ & $\begin{array}{c}1.4 \pm 0.2 \\
(5)\end{array}$ & $\begin{array}{c}2.0 \pm 1.4 \\
(11)\end{array}$ & NA & $\begin{array}{c}1.9 \pm 0.8 \\
(6)\end{array}$ \\
\hline Rhododendron oomurasaki & $\begin{array}{c}1.3 \pm 0.3 \\
(14)\end{array}$ & $\begin{array}{c}4.4 \pm 1.0 \\
(12)\end{array}$ & $\begin{array}{c}4.4 \pm 2.0 \\
(18)\end{array}$ & $\begin{array}{c}5.0 \pm 1.3 \\
(6)\end{array}$ & $\begin{array}{c}2.5 \pm 1.4 \\
(8)\end{array}$ & $\begin{array}{c}6.0 \pm 1.7 \\
(16)\end{array}$ & $\begin{array}{c}5.1 \pm 1.0 \\
(20)\end{array}$ & $\begin{array}{c}5.2 \pm 1.2 \\
(7)\end{array}$ \\
\hline
\end{tabular}

Number of samples is in parentheses

NA: not analyzed

ND : not detected 
Table 5 Heavy metal concentrations (Mean $\pm \mathrm{SD}$ on $\mu \mathrm{g} \mathrm{g}^{-1}$ dry weight basis) in the leaves of roadside trees collected from each location around Tokyo on September in 1997

\begin{tabular}{|c|c|c|c|c|c|c|c|c|}
\hline \multirow[t]{2}{*}{ Tree species } & \multirow[b]{2}{*}{ Reference site } & \multirow{2}{*}{$\begin{array}{l}\text { WA } \\
\text { Shimagawadoori }\end{array}$} & \multirow{2}{*}{$\begin{array}{l}\text { D } \\
\text { Touhachidouro }\end{array}$} & \multirow[b]{2}{*}{ Kanjyounanagousen } & \multirow[b]{2}{*}{ Reference site } & \multirow{2}{*}{$\begin{array}{l}\text { UNW } \\
\text { Shinagawadoori }\end{array}$} & \multirow{2}{*}{ Touhachidouro } & \multirow[b]{2}{*}{ Kanjyounanagousen } \\
\hline & & & & & & & & \\
\hline & \multicolumn{4}{|c|}{$\mathrm{Mn}$} & \multicolumn{4}{|c|}{ Mn } \\
\hline Zelkova serrata & $\begin{array}{c}36 \pm 4 \\
(3)\end{array}$ & NA & $\begin{array}{c}88 \pm 17 \\
(8)\end{array}$ & $\begin{array}{c}82 \pm 8 \\
(6)\end{array}$ & $\begin{array}{c}44 \pm 5 \\
(3)\end{array}$ & NA & $\begin{array}{c}100 \pm 21 \\
(8)\end{array}$ & $\begin{array}{c}87 \pm 6 \\
(6)\end{array}$ \\
\hline Ginkgo biloba & $\begin{array}{c}13 \pm 0.4 \\
(6)\end{array}$ & $\begin{array}{r}14 \pm 4 \\
(10)\end{array}$ & $\begin{array}{r}17 \pm 7 \\
(14)\end{array}$ & 19 & $18 \pm 4$ & $\begin{array}{c}16 \pm 3 \\
(11)\end{array}$ & $\begin{array}{c}20 \pm 8 \\
(14)\end{array}$ & $\begin{array}{c}23 \pm 3 \\
(6)\end{array}$ \\
\hline Cinnamomum camphora & $\begin{array}{c}41 \pm 1 \\
(4)\end{array}$ & $\begin{array}{c}45 \pm 10 \\
(8)\end{array}$ & $\begin{array}{c}57 \pm 11 \\
(9)\end{array}$ & $\begin{array}{c}83 \pm 16 \\
(9)\end{array}$ & $\begin{array}{c}45 \pm 4 \\
(4)\end{array}$ & $\begin{array}{c}49 \pm 8 \\
(11)\end{array}$ & $\begin{array}{c}64 \pm 5 \\
(9)\end{array}$ & $\begin{array}{c}87 \pm 20 \\
(10)\end{array}$ \\
\hline Acer buergerianum & $\begin{array}{c}40 \pm 4 \\
(6)\end{array}$ & $\begin{array}{c}57 \pm 4 \\
(8)\end{array}$ & NA & $\begin{array}{c}38 \pm 2 \\
(6)\end{array}$ & $\begin{array}{c}48 \pm 3 \\
(6)\end{array}$ & $\begin{array}{c}60 \pm 8 \\
(11)\end{array}$ & NA & $\begin{array}{c}43 \pm 5 \\
(6)\end{array}$ \\
\hline \multirow[t]{2}{*}{ Rhododendron oomurasaki } & $\begin{array}{c}57 \pm 9 \\
(6)\end{array}$ & $\begin{array}{c}110 \pm 13 \\
\quad(12)\end{array}$ & $\begin{array}{c}110 \pm 23 \\
(19)\end{array}$ & $\begin{array}{c}61 \pm 20 \\
(9)\end{array}$ & $\begin{array}{c}68 \pm 11 \\
(6)\end{array}$ & $\begin{array}{c}120 \pm 13 \\
(13)\end{array}$ & $\begin{array}{c}120 \pm 34 \\
(19)\end{array}$ & $\begin{array}{c}68 \pm 16 \\
(10)\end{array}$ \\
\hline & \multicolumn{4}{|c|}{$\mathrm{Fe}$} & \multicolumn{4}{|c|}{$\mathrm{Fe}$} \\
\hline Zelkova serrata & $\begin{array}{c}190 \pm 9 \\
(3)\end{array}$ & NA & $\begin{array}{c}330 \pm 37 \\
(8)\end{array}$ & $\begin{array}{c}350 \pm 9 \\
(6)\end{array}$ & $200 \pm 20$ & NA & $\begin{array}{c}350 \pm 38 \\
(8)\end{array}$ & $\begin{array}{c}410 \pm 11 \\
(6)\end{array}$ \\
\hline Ginkgo biloba & $\begin{array}{c}180 \pm 27 \\
(6)\end{array}$ & $\begin{array}{c}200 \pm 45 \\
(10)\end{array}$ & $\begin{array}{c}210 \pm 22 \\
(14)\end{array}$ & 300 & $\begin{array}{c}180 \pm 33 \\
(6)\end{array}$ & $\begin{array}{c}230 \pm 36 \\
(11)\end{array}$ & $\begin{array}{c}220 \pm 62 \\
(14)\end{array}$ & $\begin{array}{c}320 \pm 25 \\
(6)\end{array}$ \\
\hline Cinnamomum camphora & $\begin{array}{c}240 \pm 32 \\
(4)\end{array}$ & $\begin{array}{c}260 \pm 52 \\
(8)\end{array}$ & $\begin{array}{c}140 \pm 26 \\
(9)\end{array}$ & $\begin{array}{c}270 \pm 48 \\
(9)\end{array}$ & $\begin{array}{c}240 \pm 38 \\
(4)\end{array}$ & $\begin{array}{c}280 \pm 24 \\
\quad(11)\end{array}$ & $\begin{array}{c}200 \pm 25 \\
(9)\end{array}$ & $\begin{array}{c}320 \pm 34 \\
(10)\end{array}$ \\
\hline Acer buergerianum & $\begin{array}{c}160 \pm 41 \\
(6)\end{array}$ & $\begin{array}{c}270 \pm 29 \\
(8)\end{array}$ & NA & $\begin{array}{c}300 \pm 44 \\
(6)\end{array}$ & $\begin{array}{c}180 \pm 20 \\
(6)\end{array}$ & $\begin{array}{c}300 \pm 74 \\
(11)\end{array}$ & NA & $\begin{array}{c}310 \pm 37 \\
(6)\end{array}$ \\
\hline \multirow[t]{2}{*}{ Rhododendron oomurasaki } & $\begin{array}{c}410 \pm 15 \\
(6)\end{array}$ & $\begin{array}{c}870 \pm 180 \\
(12)\end{array}$ & $\begin{array}{c}750 \pm 160 \\
(19)\end{array}$ & $\begin{array}{c}900 \pm 310 \\
(9)\end{array}$ & $\begin{array}{c}500 \pm 110 \\
(6)\end{array}$ & $\begin{array}{c}970 \pm 200 \\
(13)\end{array}$ & $\begin{array}{c}860 \pm 230 \\
(19)\end{array}$ & $\begin{array}{c}980 \pm 380 \\
(10)\end{array}$ \\
\hline & \multicolumn{4}{|c|}{$\mathrm{Cu}$} & \multicolumn{4}{|c|}{$\mathrm{Cu}$} \\
\hline Zelkova serrata & $\begin{array}{c}4.8 \pm 0.8 \\
(3)\end{array}$ & NA & $\begin{array}{c}5.7 \pm 1.2 \\
(8)\end{array}$ & $\begin{array}{c}6.9 \pm 0.4 \\
(6)\end{array}$ & $\begin{array}{c}5.2 \pm 0.2 \\
(3)\end{array}$ & NA & $\begin{array}{c}7.0 \pm 1.4 \\
(8)\end{array}$ & $\begin{array}{c}9.0 \pm 1.5 \\
(6)\end{array}$ \\
\hline Ginkgo biloba & $\begin{array}{c}2.2 \pm 0.2 \\
(6)\end{array}$ & $\begin{array}{c}4.3 \pm 0.9 \\
(10)\end{array}$ & $\begin{array}{c}4.1 \pm 0.3 \\
(14)\end{array}$ & 5.7 (1) & $\begin{array}{c}2.4 \pm 0.3 \\
(6)\end{array}$ & $\begin{array}{c}4.8 \pm 0.6 \\
(11)\end{array}$ & $\begin{array}{c}4.4 \pm 0.5 \\
(14)\end{array}$ & $\begin{array}{c}6.1 \pm 0.6 \\
(6)\end{array}$ \\
\hline Cinnamomum camphora & $\begin{array}{c}4.7 \pm 0.3 \\
(4)\end{array}$ & $\begin{array}{c}9.1 \pm 1.6 \\
(8)\end{array}$ & $\begin{array}{c}5.0 \pm 2.1 \\
(9)\end{array}$ & $\begin{array}{c}11 \pm 1 \\
(9)\end{array}$ & $\begin{array}{l}5.1 \pm 0.3 \\
(4)\end{array}$ & $\begin{array}{c}10 \pm 1 \\
(11)\end{array}$ & $\begin{array}{c}7.6 \pm 0.9 \\
(9)\end{array}$ & $\begin{array}{c}12 \pm 1 \\
(10)\end{array}$ \\
\hline Acer buergerianum & $\begin{array}{c}5.7 \pm 1.2 \\
(6)\end{array}$ & $\begin{array}{c}9.1 \pm 1.2 \\
(8)\end{array}$ & NA & $\begin{array}{c}11 \pm 1 \\
(6)\end{array}$ & $\begin{array}{c}7.1 \pm 0.7 \\
(6)\end{array}$ & $\begin{array}{r}11 \pm 1 \\
(11)\end{array}$ & NA & $\begin{array}{c}14 \pm 1 \\
(6)\end{array}$ \\
\hline \multirow[t]{2}{*}{ Rhododendron oomurasaki } & $\begin{array}{c}10 \pm 1 \\
(6)\end{array}$ & $\begin{array}{c}17 \pm 3 \\
(12)\end{array}$ & $\begin{array}{c}16 \pm 3 \\
(19)\end{array}$ & $\begin{array}{c}22 \pm 5 \\
(9)\end{array}$ & $\begin{array}{c}11 \pm 1 \\
(6)\end{array}$ & $\begin{array}{r}20 \pm 3 \\
(13)\end{array}$ & $\begin{array}{r}20 \pm 2 \\
(19)\end{array}$ & $\begin{array}{r}26 \pm 5 \\
(10)\end{array}$ \\
\hline & \multicolumn{4}{|c|}{$\mathrm{Zn}$} & \multicolumn{4}{|c|}{$\mathrm{Zn}$} \\
\hline Zelkova serrata & $\begin{array}{c}11 \pm 3 \\
(3)\end{array}$ & NA & $\begin{array}{c}30 \pm 4 \\
(8)\end{array}$ & $\begin{array}{c}18 \pm 2 \\
(6)\end{array}$ & $\begin{array}{c}13 \pm 2 \\
(3)\end{array}$ & NA & $\begin{array}{c}37 \pm 7 \\
(8)\end{array}$ & $\begin{array}{c}28 \pm 2 \\
(6)\end{array}$ \\
\hline Ginkgo biloba & $\begin{array}{c}7 \pm 0.4 \\
(6)\end{array}$ & $\begin{array}{c}9 \pm 2 \\
(10)\end{array}$ & $\begin{array}{r}11 \pm 1 \\
(14)\end{array}$ & 12 & $\begin{array}{c}7 \pm 1 \\
(6)\end{array}$ & $\begin{array}{c}20 \pm 4 \\
(11)\end{array}$ & $\begin{array}{c}17 \pm 2 \\
(14)\end{array}$ & $\begin{array}{c}17 \pm 2 \\
(6)\end{array}$ \\
\hline Cinnamomum camphora & $\begin{array}{c}13 \pm 0.4 \\
(4)\end{array}$ & $\begin{array}{c}25 \pm 5 \\
(8)\end{array}$ & $\begin{array}{c}16 \pm 7 \\
(9)\end{array}$ & $20 \pm 4$ & $\begin{array}{c}14 \pm 1 \\
(4)\end{array}$ & $\begin{array}{c}33 \pm 6 \\
(11)\end{array}$ & $\begin{array}{c}22 \pm 3 \\
(9)\end{array}$ & $\begin{array}{c}30 \pm 5 \\
(10)\end{array}$ \\
\hline Acer buergerianum & $\begin{array}{c}28 \pm 2 \\
(6)\end{array}$ & $\begin{array}{c}36 \pm 10 \\
(8)\end{array}$ & NA & $\begin{array}{c}39 \pm 6 \\
(6)\end{array}$ & $\begin{array}{c}30 \pm 2 \\
(6)\end{array}$ & $\begin{array}{r}49 \pm 8 \\
(11)\end{array}$ & NA & $\begin{array}{c}50 \pm 5 \\
(6)\end{array}$ \\
\hline \multirow[t]{2}{*}{ Rhododendron oomurasaki } & $\begin{array}{c}37 \pm 1 \\
(6)\end{array}$ & $\begin{array}{c}89 \pm 5 \\
(12)\end{array}$ & $\begin{array}{c}64 \pm 12 \\
(19)\end{array}$ & $\begin{array}{c}80 \pm 14 \\
(9)\end{array}$ & $\begin{array}{c}45 \pm 3 \\
(6)\end{array}$ & $\begin{array}{c}120 \pm 27 \\
(13)\end{array}$ & $\begin{array}{c}100 \pm 16 \\
(19)\end{array}$ & $\begin{array}{r}110 \pm 7 \\
(10)\end{array}$ \\
\hline & \multicolumn{4}{|c|}{$\mathrm{Cd}$} & \multicolumn{4}{|c|}{$\mathrm{Cd}$} \\
\hline Zelkova serrata & $\begin{array}{c}0.01 \pm 0.01 \\
(3)\end{array}$ & NA & $\begin{array}{c}0.03 \pm 0.02 \\
(8)\end{array}$ & $\begin{array}{c}0.02 \pm 0.01 \\
(6)\end{array}$ & $0.05 \pm 0.03$ & NA & $\begin{array}{c}0.22 \pm 0.05 \\
(8)\end{array}$ & $\begin{array}{c}0.17 \pm 0.06 \\
(6)\end{array}$ \\
\hline Ginkgo biloba & $\begin{array}{c}0.01 \pm 0.01 \\
(5)\end{array}$ & ND & $\begin{array}{c}0.005 \pm 0.010 \\
(11)\end{array}$ & ND & $\begin{array}{c}0.03 \pm 0.02 \\
(4)\end{array}$ & $\begin{array}{c}0.04 \pm 0.03 \\
(5)\end{array}$ & $\begin{array}{c}0.07 \pm 0.08 \\
(8)\end{array}$ & $\begin{array}{c}0.12 \pm 0.03 \\
(6)\end{array}$ \\
\hline Cinnamomum camphora & $\begin{array}{c}0.01 \pm 0.01 \\
(4)\end{array}$ & $\begin{array}{c}0.01 \pm 0.01 \\
(8)\end{array}$ & $\begin{array}{c}0.03 \pm 0.01 \\
(6)\end{array}$ & $\begin{array}{c}0.06 \pm 0.04 \\
(9)\end{array}$ & $\begin{array}{c}0.04 \pm 0.04 \\
(3)\end{array}$ & $\begin{array}{c}0.13 \pm 0.07 \\
(11)\end{array}$ & $\begin{array}{c}0.16 \pm 0.06 \\
(8)\end{array}$ & $\begin{array}{c}0.31 \pm 0.12 \\
(10)\end{array}$ \\
\hline Acer buergerianum & $\begin{array}{c}0.10 \pm 0.06 \\
(6)\end{array}$ & $\begin{array}{c}0.05 \pm 0.02 \\
(8)\end{array}$ & NA & $\begin{array}{c}0.04 \pm 0.02 \\
(6)\end{array}$ & $\begin{array}{c}0.09 \pm 0.06 \\
(6)\end{array}$ & $\begin{array}{c}0.21 \pm 0.03 \\
(11)\end{array}$ & NA & $\begin{array}{c}0.30 \pm 0.10 \\
(6)\end{array}$ \\
\hline \multirow[t]{2}{*}{ Rhododendron oomurasaki } & $\begin{array}{c}0.19 \pm 0.02 \\
(6)\end{array}$ & $\begin{array}{c}0.32 \pm 0.20 \\
(12)\end{array}$ & $\begin{array}{c}0.35 \pm 0.11 \\
(19)\end{array}$ & $\begin{array}{c}0.24 \pm 0.03 \\
(9)\end{array}$ & $\begin{array}{c}0.27 \pm 0.08 \\
(6)\end{array}$ & $\begin{array}{c}0.95 \pm 0.36 \\
(13)\end{array}$ & $\begin{array}{c}1.6 \pm 0.5 \\
(19)\end{array}$ & $\begin{array}{c}1.0 \pm 0.2 \\
(10)\end{array}$ \\
\hline & \multicolumn{4}{|c|}{$\mathrm{Pb}$} & \multicolumn{4}{|c|}{$\mathrm{Pb}$} \\
\hline Zelkova serrata & $\begin{array}{c}1.1 \pm 0.4 \\
(3)\end{array}$ & NA & $\begin{array}{c}3.5 \pm 1.0 \\
(8)\end{array}$ & $\begin{array}{c}3.2 \pm 0.5 \\
(6)\end{array}$ & $\begin{array}{c}1.1 \pm 0.4 \\
(3)\end{array}$ & NA & $\begin{array}{c}3.6 \pm 0.7 \\
(8)\end{array}$ & $\begin{array}{c}3.5 \pm 0.5 \\
(6)\end{array}$ \\
\hline Ginkgo biloba & $\begin{array}{c}0.8 \pm 0.4 \\
(6)\end{array}$ & $\begin{array}{c}1.0 \pm 0.4 \\
(9)\end{array}$ & $\begin{array}{c}1.7 \pm 1.2 \\
(14)\end{array}$ & 1.4 & $\begin{array}{c}1.0 \pm 0.1 \\
(6)\end{array}$ & $\begin{array}{c}1.2 \pm 0.3 \\
(11)\end{array}$ & $\begin{array}{c}1.9 \pm 0.8 \\
(14)\end{array}$ & $\begin{array}{c}2.5 \pm 0.3 \\
(6)\end{array}$ \\
\hline Cinnamomum camphora & $\begin{array}{c}1.0 \pm 0.2 \\
(4)\end{array}$ & $\begin{array}{c}1.0 \pm 0.3 \\
(8)\end{array}$ & $\begin{array}{c}1.1 \pm 0.3 \\
(9)\end{array}$ & $\begin{array}{c}1.9 \pm 0.2 \\
(9)\end{array}$ & $\begin{array}{c}1.0 \pm 0.2 \\
(4)\end{array}$ & $\begin{array}{c}1.9 \pm 0.8 \\
(11)\end{array}$ & $\begin{array}{c}1.3 \pm 0.3 \\
(9)\end{array}$ & $\begin{array}{c}2.7 \pm 0.4 \\
(10)\end{array}$ \\
\hline Acer buergerianum & $\begin{array}{c}0.8 \pm 0.4 \\
(6)\end{array}$ & $\begin{array}{c}1.8 \pm 0.6 \\
(7)\end{array}$ & NA & $\begin{array}{c}1.2 \pm 0.6 \\
(6)\end{array}$ & $\begin{array}{c}1.3 \pm 0.1 \\
(6)\end{array}$ & $\begin{array}{c}2.1 \pm 0.7 \\
(11)\end{array}$ & NA & $\begin{array}{c}2.8 \pm 0.5 \\
(6)\end{array}$ \\
\hline Rhododendron oomurasaki & $\begin{array}{c}1.7 \pm 0.2 \\
(6)\end{array}$ & $\begin{array}{c}3.7 \pm 0.6 \\
(12)\end{array}$ & $\begin{array}{c}4.6 \pm 1.7 \\
(19)\end{array}$ & $\begin{array}{c}5.4 \pm 1.4 \\
(9)\end{array}$ & $\begin{array}{c}2.3 \pm 1.2 \\
(6)\end{array}$ & $\begin{array}{c}5.6 \pm 1.5 \\
(13)\end{array}$ & $\begin{array}{c}6.4 \pm 1.0 \\
(19)\end{array}$ & $\begin{array}{c}8.0 \pm 1.9 \\
(10)\end{array}$ \\
\hline
\end{tabular}


方でイチョウが最も低くなる傾向が認められた。さら に, Mnは高木での濃度が比較的高くなるという, 特徵 的な傾向がみられた。

顕著な高濃度が認められたオオムラサキの各元素濃度 について，他の 4 樹種に対する比率（各地点に打ける各 樹種の平均濃度 (Table 4, 5) から算出した值の, 全種, 全地点を含む平均值）を検討したところ， $\mathrm{Zn}$ および $\mathrm{Cd}$ はオオムラサキでとくに高くなる傾向がみられた (Table 6)。このことは, 街路樹葉表面の立体構造や, そ の場に扔ける吸着元素の微少な動態の差異に起因し, 樹 種によって蓄積しやすい元素を異にする可能性を示唆し ている。Znは加硫促進剤としてタイヤに添加されたも のが摩耗し，また $\mathrm{Cd}$ は， $\mathrm{Zn}$ の不純物として環境中に負 荷されることが知られている。路面近くのオオムラサキ は, 粉塵中の特定画分に偏在するこれらの元素を, とく に効果的に捕捉する可能性が推察された。

今回調查対象とした 5 樹種のうち, オオムラサキのみ は低木であり, 葉の採取高さ及び植栽状況が他の 4 樹種 とは異なる。複層構造をもつ都市近郊林の樹木葉では, 中下層木の旧年葉がとくに多くの粉塵粒子を補足すると の報告がある 23 。本調査結果に扔いても，高木の葉に付 着した重金属類を含む粉塵粒子が，降雨により洗脱さ れ, 高木下のオオムラサキの葉に再付着した可能性も推 察された。しかし，オオムラサキと他樹種との元素濃度 の比率をみると, 充実した複層構造をもつ東八道路の街 路樹において, 本種が顕著な重金属蓄積を示す傾向は認 められなかった。このことから, 本調查で明らかになっ たオオムラサキの顕著な高濃度は, 植栽構造よりも, む しろ植栽高さや葉の性状に起因すると推察され, 本種の 葉面に密生した葉毛が, 効果的に粉塵粒子を捕捉してい る可能性が考えられた。

また街路樹葉の重金属類は，6月から 9 月にかけて， $\mathrm{Mn}, \mathrm{Fe}, \mathrm{Cd}, \mathrm{Pb}$ の濃度が上昇した。この経時的な増加 パターンは, とくに交通量の多い環状七号線で認めら れ, また樹種では, 他種に比べ高濃度の重金属を蓄積し ていたオオムラサキで顕著であった。加えて, 洗浄葉お よび未洗浄葉ともに濃度が上昇していたことから，4元 素の蓄積は曝露量に依存し，さらに，葉内あるいは葉表
面に堅く保持されている可能性を示唆している。一方, $\mathrm{Cu}$ と $\mathrm{Zn}$ 濃度は，6月から 9 月にかけて減少する傾向が みられた。このことは, 両元素の葉による捕捉が緩や か, もしくは一時的であると考えられ，風雨等の作用に より洗脱され易いことが考えられた。

\section{4. おわりに}

東京都内の道路粉塵の重金属濃度は, 交通量の増加に 伴う上昇傾向が認められ, さらに街路土壤は参照地とし て設定した非街路土壤よりも高レベルの重金属を含有し ていることが明らかとなった。これらの結果は, 重金属 類による沿道污染が, 都市においては身近な環境問題で あること，無制限な交通網の拡大が，污染をさらに広げ る危険性があることを示唆している。また，かつて自動 車による重金属污染の代表であった $\mathrm{Pb}$ による污染が, やや軽減している経年变化もうかがわれたが, 街路土壤 の濃度は依然高く, 長期間にわたる污染が存在している ことも懸念された。さらに排気浄化のためのシステム が, Ptなど新たな元素污染を引き起こしている可能性も 明らかとなり，今後の詳細かつ継続的なモニタリングの 必要性を示唆していよう。

街路樹は, 参照地の同樹種よりも重金属類を高濃度で 葉に蓄積していることが明らかとなり，その捕捉量は樹 種により大きな違いがあることが示された。さらに樹 種, あるいは植栽の高さにより, 捕捉されやすい元素が 異なる可能性もうかがえ，このことは，樹木が有する粒 子状污染物質の捕捉効果を考慮した樹種選定や植栽設計 が，道路周辺に扔ける重金属污染の拡散を，効果的に防 止する可能性を示唆している。とくに, 自動車の走行に 由来する $\mathrm{Cu}$ や $\mathrm{Pb}$ 粒子は粒径が小さいため, 沿道に留ま らず遠くまで飛散すると考えられており ${ }^{24)}$ ，沿道植栽に よる拡散防止は都市における大気環境の改善に大きく貢 献することが期待される。本研究では葉の乾重当たりの 捕捉量のみを対象としたが, 樹木当たりの捕捉量や植栽 状況による効果の比較など, さらに検討すべき点は多 い。これらの課題を詳細に検討することは，低コストな クリーン・テクノロジーであるファイト・レメディエー ションの利点を最大限に活かした現実的技術となる可能

Table 6 Mean concentration ratio of 6 elements in $R$. oomurasaki to in other species ( $\mathrm{n}=14$; Mean concentration of $R$. oomurasaki/mean concentration of the other species from all locations)

\begin{tabular}{|c|c|c|c|c|c|c|}
\hline Treatment \& season & $\mathrm{Mn}$ & $\mathrm{Fe}$ & $\mathrm{Cu}$ & $\mathrm{Zn}$ & $\mathrm{Cd}$ & $\mathrm{Pb}$ \\
\hline Washed leaf in June & $1.3 \pm 0.7$ & $2.9 \pm 0.7$ & $2.3 \pm 1.3$ & $4.1 \pm 2.9$ & - & $4.0 \pm 2.9$ \\
\hline Unwashed leaf in June & $1.3 \pm 0.7$ & $3.0 \pm 0.7$ & $2.2 \pm 1.2$ & $3.5 \pm 1.8$ & $15 \pm 15$ & $2.7 \pm 0.8$ \\
\hline Washed leaf in September & $2.6 \pm 2.1$ & $3.1 \pm 0.9$ & $2.8 \pm 0.9$ & $4.1 \pm 2.1$ & $20 \pm 20$ & $2.7 \pm 1.0$ \\
\hline Unashed leaf in September & $2.5 \pm 1.8$ & $3.1 \pm 0.7$ & $2.9 \pm 1.1$ & $4.1 \pm 1.6$ & $8.7 \pm 6.4$ & $2.8 \pm 0.9$ \\
\hline
\end{tabular}


性があり，実用を視野に入れた研究は意義が大きいと言 えよう。

\section{要 約}

東京都内の主要道路から, 道路粉塵, 街路土壌および 街路樹の葉を採取し, $\mathrm{Mn}, \mathrm{Fe}, \mathrm{Cu}, \mathrm{Zn}, \mathrm{Cd}, \mathrm{Pt}, \mathrm{Pb}$ 濃 度を測定した。交通量が最大であった環状七号線の道路 粉塵は, 高濃度の $\mathrm{Cu}, \mathrm{Zn}, \mathrm{Pt}, \mathrm{Pb}$ が検出され, 自動車走 行の影響が推察された。

街路樹葉の重金属濃度はいずれも, 非道路脇で採取さ れた試料の約 1〜4倍であった。樹種による濃度差が顕 著であり, オオムラサキで最高, イチョウで最低となっ た。重金属類は葉内あるいは葉表面に蓄積され易く, 樹 種による濃度差は, 植栽の高さや葉の性状の違いに起因 することが考えられた。街路樹種の選定に金属捕捉の視 点を加味することは, 効果的な道路周辺環境の改善に活 用できよう。

\section{文 献}

1）環境庁沿道大気污染状況研究会 監: 道路周辺の大 気污染状況10. ぎょうせい, pp11-61（1999）

2) 朝日新聞社：朝日新聞朝刊13版. 2000年10月16日つ it (2000)

3) Foner, H.A.: Traffic lead pollution of some edible crops in Israel. The Science of Total Environment, 59, pp309-315 (1987)

4）坂上寛一, 宮田千春, 梶田初美, 菅原十一, 浜田竜 之介：降下ばいじんによる重金属の土壤への付与, 土肥誌，52，pp181-186（1981）

5) Sadiq, M., Alam, I., El-Mubarek, A. and AlMohdhar, H.M.: Preliminary evaluation of metal pollution from wear of auto tires. Bull. Environ. Contam. Toxicol, 42, pp743-748 (1989)

6) 日本自動車教育振興財団：「自動車, そして人」, pp90-91 (1997)

7) Wei, C. and Morrison, G.M.: Platinum in road dust and urban river sediments. The Science of the Total Environment, 146/147, pp169-174 (1994)

8） Muhammed, T., 鈴木義則 : 街路樹の都市表面温度 抑制効果について, 九州大学農学部学芸雑誌, 51, pp179-185 (1997)

9）環境庁内環境保全関係法令研究会：「環境保全関係 法令質疑応答集追録別冊」, pp95-110（1989）
10) Nizar, N., Hideki, T. and Akira, M.: Effect of roadside planting on suspended particulate matter concentration near road. Environmental Technology, 15, pp293-298 (1994)

11）三沢 彰, 町田千鶴：沿道植栽木の樹葉による粉塵 吸着·吸収特性に関する研究, 造園雑誌, 49, pp 125 -130 (1986)

12）東京都環境保全局環境管理部：「東京都環境白書資 料集」, pp32-53 (1998)

13）調布市：「調布市交通量調査（幹線道路調査報告 書)」, pp60-64 (1997)

14）東京都建設局道路建設部：「交通量調査報告書（1/2 区部，2/2市郡部) 」，pp113-253（1995）

15）本間 慎, 白田和人：群馬県安中市の亜鉛製錬所に よる桑樹の重金属污染について, 日蚕誌，46， pp159-166 (1977)

16）渡邊 泉, 前畑亜希子, 尾崎宏和, 久野勝治: 日光 国立公園尾瀬周辺における道路粉塵の重金属濃度と その地理的分布および季節変動, 一 1999年の調 査一. 環境科学会誌, 15, pp113-125 (2002)

17）土培標準分析·測定法委員会：「土壌標準分析・測定 法」 pp 70-71, 博友社, 東京 (1986)

18) Taylor, S.R. and McLennan, S.M.: "The continental crust: its composition and evolution". Blackwell Sci. Pub. London, 312p (1985)

19) Mason, B. and Moore C.B.: "Principles of geochemistry 4th ed”. John Wiley \& Sons, New York, 350p (1982)

20）浅見輝男，手島礼子：規模の異なる都市の道路わき 粉じんの重金属含有率, 茨城大農学術報告, 26, pp117-125（1978）

21）東京都環境局：「東京都環境白書2000」, pp32-37 (2000)

22）嶋田典司, 住吉雅己, 豊田正司, 佐藤幸夫, 小島道 也：道路周辺の土壤及び植物の鉛, 亜鉛, カドミウ ムによる污染，千葉大園学報，21，pp65-73（1973）

23）嶋一徹, 松崎由利子, 千葉喬三：都市近郊林にお ける浮遊重金属補足機能に関する研究, 日本緑化工 学会誌, 19, pp1-10（1993）

24）位地正午, 鶴見 実, 一国雅巳：首都圏の降下物に 含まれる金属元素, 地球化学, 17, pp93-101 (1983) 